\title{
Effect of Physico-Chemical Conditions on the Structure and Composition of the Phytoplankton Community at Jatinangor, Indonesia
}

\author{
R.A. Yousif ${ }^{1 *}$, Masyamsir ${ }^{2}$, Dhahiyat ${ }^{2}$, Sunarto $^{2}$ and Zahidah $^{2}$ \\ ${ }^{1}$ Department of Fisheries and Wildlife Science, Sudan University of Science and Technology, \\ P.O.BOX204, Khartoum, Sudan \\ ${ }^{2}$ Faculty of Fisheries and Marine Science, Universitas Padjadjaran, J1.21.Jatinangor, Indonesia \\ *Corresponding author
}

\section{A B S T R A C T}

This study was conducted to evaluate the impact of activities in campus Universitas Padjadjaran (UNPAD) on the water quality as a result of the entery and discharge of pollution materials from laboratories, food courts, agriculture and domestic waste in campus UNPAD to Check dam UNPAD, Ciparanje and Cikuda River. Very limited

\section{Keywords}

Pollution, Water Quality, Check dam UNPAD, Cikuda River.

Article Info

Accepted:

28 September 2017 Available Online:

10 November 2017 information is available on the phytoplankton status and the effect of water pollution on the phytoplankton population of this area. Thus the present study was undertaken to study the seasonal diversity and the physico-chemical properties of water for five sampling localities were selected for the present study depending upon the anthropogenic activities around the Campus UNPAD, water samples at selected points were analysed for $\mathrm{pH}$ ranged from 5.45- 8.97, DO 4.3-8.9 $\mathrm{mg} \mathrm{L}^{-1}$, BOD 0.27 - 15.78 $\mathrm{mg} \mathrm{L}^{-1}, \mathrm{PO}_{4} 0.080-0.611 \mathrm{mg}$ $\mathrm{L}^{-1}, \mathrm{NH}_{3}-\mathrm{N} 0.0001-1.150 \mathrm{mg} \mathrm{L}{ }^{-1}, \mathrm{NO}_{3}-\mathrm{N} 0.333-2.820 \mathrm{mg} \mathrm{L}^{-1}$. Spatial and temporal distribution of phytoplankton was studied in detail, the results showed that, the total number of phytoplankton classes were 8 in five different stations studied which comprises 42 different genera, the genus are represented by 10 genus Chlorophyceae, 14 genus Bacillariophyceae, 10 genus Cyanophyceae, 4 genus Euglenophyceae, 1 genus Coscinodiscophyceae, 1 genus Florideophyceae, 1 genus Xanthophyceae and 1 genus Zygnematophyceae. Among phytoplankton various species of Bacillariophyceae were dominant throughout the study period, with changes in temperature and phytoplankton composition density of phytoplankton exhibited during the dry season.

\section{Introduction}

Phytoplankton is a key component of the waterbody biota in general, because it forms the base of the pyramid of productivity. Assuming that any increase in nutrient inputs leads to enhanced primary productivity, phytoplankton may serve as a relevant indicator of the trophic state in water (SzelaggWasielewska, 2006). Phytoplankton is the chief primary producer of the aquatic environment which fixes solar energy by process of photosynthesis, assimilating carbon dioxide and water to produce carbohydrates. Phytoplanktonic species have different physiological requirements and thus show diverse responses to physical and chemical parameters such as light, temperature and nutrient regime. Their sensitivity and variations in species composition are often a 
reflection of significant alteration in ambient condition within an ecosystem (Devassy and Goes, 1988, 1989). Hence before any utilization of lake resources comes into consideration, plankton study is of primary interest. Earlier studies on phytoplankton diversity (Pieterse and Van, 1988; Vaulot, 2001; Pongswat et al., 2000; Kendirim, 2001; Millman et al., 2005; Tiwari and Chauhan, 2006; Sridhar et al., 2006; Tas and Gonulol, 2007; Senthilkumar and Sivakumar, 2008; Ganai et al., 2010), revealed the importance of this type of study. Studies showed that most of the phytoplankton was a great deal sensitive to the varying environment condition. That is to say, a negative change in phytoplankton composing the primary productivity affects all living creatures. Therefore, phytoplankton that is composed of the first ring of food chain should be examined taxo-nomically and ecologically. Algae are a large and diverse group of simple plants ranging from unicellular to multicellular form. These are considered as the first autotrophic (photosynthetic) plants of the planet. Algae are ubiquitous, that occur in almost all habitats, ranging from marine and freshwater to desert sands and from hot springs to snow.

The habitats occupied by fresh water algae are divided into lotic (running) and lentic (stagnant) water types (Lone et al., 2016). Due to the growth of algae in different habitats, they may be variable and highly diversified group of green plants i.e., phytoplanktonic (free floating), benthos (attached to sediments), epiphytic (on plants), epilithic (on stones), epipelic (on sand), endophytic (inside the plant), epizoic (on shells), and endozoic (inside sponge). They have enormous economic implications, not only as primary producers and pollution indicators but also as a source of several natural products, biofertilizers, fine chemicals (Lone et al., 2013; Chisti, 2007).

\section{Materials and Methods}

The present study results from limnological investigation undertaken during the dry season (July-September 2015) and wet season (December 2015-February 2016), on Check dam UNPAD, Bandung, Indonesia (Inlet S $06^{\circ} 55^{\prime}$ 51.26" E $107^{\circ} 46^{\prime}$ 24.35", Centre S $06^{\circ} 55^{\prime} 52.24^{\prime \prime}$ E $107^{\circ} 46^{\prime} 26.85$, Outlet S $06^{\circ}$ 55' 54.94" E $107^{\circ} 46^{\prime}$ 27.01', Cikuda River S $06^{\circ} 55^{\prime} 44.78^{\prime \prime}$ E $107^{\circ} 46^{\prime}$ 53.52" and Ciparanje S $06^{\circ}$ 54' 37.14" E $107^{\circ} \quad 46^{\prime}$ 13.17'). The Check dam UNPAD is chiefly fed by streams which flows from Campus UNPAD. The water samples were collected from selected sites during morning hours in two liters polythene bottles for physicochemical parameters between 7:00 A.M. to 11:00 A.M. Water temperature, $\mathrm{pH}$, transparency and DO were determined on the sampling sites, while $\mathrm{BOD}, \mathrm{NH}_{3}, \mathrm{NO}_{3}$ and $\mathrm{PO}_{4}$ were analyzed in the laboratory by using standard methods of APHA, (2005).

For the plankton analysis, the samples were collected by filtering 10 liters of water filtered through plankton net of $20 \mu$ pore size filtering cloth and concentrated up to $100 \mathrm{ml}$. The concentrated plankton samples were preserved immediately with the help of $5 \mathrm{ml}$ of Lugol's Iodine solution (Edmondson, 1959). The samples were observed under the microscope and identified phytoplankton using standard keys and published literature. The phytoplankton species have been identified by using keys - Edmondson, W.T.(1959) and Adoni, A. D. et al., (1985). Counting was made by putting one drop of concentrate on a slide and observing the content under inverted microscope (Metzer). Results were expressed in No. $/ \mathrm{ml}$.

Diversity index Shannon - Weaver (1949) and correlation coefficient were also calculated. Shannon Weaver diversity index (H') was calculated using the following formula: 
Shannon - Wiener Index $(H)=\Sigma n i / N$ In ni $/ \mathrm{N}$

Where:

$\mathrm{H}=$ Shannon -Weaver index of diversity;

$\mathrm{ni}=$ total numbers of individuals of species,

$\mathrm{N}=$ total number of individual of all species.

\section{Results and Discussion}

Species composition of phytoplankton its varied during this research that is depend on the location and also the seasonility. The results showed that, the total number of phytoplankton classes were 8 in five different stations studied which comprises 42 different genera, the genus are represented by 10 genus Chlorophyceae, 14 genus Bacillariophyceae, 10 genus Cyanophyceae, 4 genus Euglenophyceae, 1 genus Coscinodiscophyceae, 1 genus Florideophyceae, 1 genus Xanthophyceae and 1 genus Zygnematophyceae (Figure 1).

The seasonal variation in the species diversity index $\left(\mathrm{H}^{\prime}\right)$ have been calculated and presented in (Table 3) for all the Five stations. The abundance of phytoplankton during the dry and wet season ranged from 700-10912.5 Cell $\mathrm{L}^{-1}$. The low abundance of phytoplankton during the wet season due to low amount of nutrients and also the entry of fresh rain water into the Check dam UNPAD, Cikuda River and Ciparanje. Succession of phytoplankton communities is affected by strong seasonal influence (Fig. 2).

Occurrence of phytoplankton groups shows a gradual increase from July to September during the dry months, with a peak in September. The population slowly declines till February at all stations. This may be due to the changes in temperature.

The high biomass in dry season could be the result of higher temperature and quantity of essential nutrients. Changes in the composition of plankton biomass perhaps are affected by predation and grazing which complicates the interpretation of population dynamics of phytoplankton in the Ckeck dam UNPAD, Cikuda River and Ciparanje (Fig. 3 and 4).

Table.1 The average of physico-chemical parameters in water during the period of this study

\begin{tabular}{|c|c|c|c|c|}
\hline \multicolumn{2}{|l|}{ Parameters } & Dry season & Wet season & Average \\
\hline \multicolumn{2}{|l|}{ Temperature } & $23.90 \pm 1.35$ & $25.63 \pm 1.64$ & $24.77 \pm 1.22$ \\
\hline \multicolumn{2}{|l|}{ Transparency } & $38.17 \pm 4.48$ & $72.90 \pm 9.19$ & $55.54 \pm 2456$ \\
\hline \multicolumn{2}{|l|}{$\mathrm{pH}$} & $7.19 \pm 0.45$ & $7.86 \pm 0.39$ & $7.53 \pm 0.47$ \\
\hline \multicolumn{2}{|l|}{ DO } & $5.61 \pm 1.25$ & $5.42 \pm 0.59$ & $5.52 \pm 0.13$ \\
\hline \multicolumn{2}{|l|}{ BOD } & $5.05 \pm 2.47$ & $2.64 \pm 0.56$ & $3.85 \pm 1.70$ \\
\hline \multicolumn{2}{|c|}{ Orthophosphate } & $0.194 \pm 0.037$ & $0.346 \pm 0.067$ & $0.270 \pm 0.107$ \\
\hline \multicolumn{2}{|c|}{ Ammonia $\left(\mathrm{NH}_{3}\right)$} & $0.0014 \pm 0.0007$ & $0.0662 \pm 0.0436$ & $0.0338 \pm 0.0458$ \\
\hline \multicolumn{2}{|c|}{ Nitrate $\left(\mathrm{NO}_{3}-\mathrm{N}\right)$} & $0.675 \pm 0.360$ & $1.130 \pm 0.432$ & $0.903 \pm 0.322$ \\
\hline \multirow{3}{*}{ Heavy Metals } & $\mathrm{Pb}$ & $0.068 \pm 0.043$ & $0.000 \pm 0.000$ & $0.034 \pm 0.047$ \\
\hline & $\mathrm{Zn}$ & $0.033 \pm 0.028$ & $0.034 \pm 0.025$ & $0.034 \pm 0.007$ \\
\hline & $\mathrm{Mn}$ & $0.034 \pm 0.049$ & $0.193 \pm 0.297$ & $0.114 \pm 0.112$ \\
\hline
\end{tabular}


Table.2 Abundance of phytoplankton during the different season

\begin{tabular}{|l|c|c|c|}
\hline \multirow{2}{*}{ Stations } & \multicolumn{2}{|c|}{ The abundance of phytoplankton $\left(\right.$ Cell L $\left.^{-1}\right)$} & \multirow{2}{*}{ Average } \\
\cline { 2 - 3 } & Dry Season & Wet Season & 3799.15 \\
\hline Inlet & 6198.3 & 1400 & 3039.57 \\
\hline Center & 3245.83 & 2833.3 & 1485.40 \\
\hline Outlet & 1833.3 & 1137.5 & 2162.52 \\
\hline Cikuda & 2770.83 & 1554.2 & 5806.25 \\
\hline Ciparanje & 10912.5 & 700 & \\
\hline
\end{tabular}

Table.3 Average of Shannon-Wiener Diversity Index $\left(\mathrm{H}^{\prime}\right)$ of Phytoplankton during the different season

\begin{tabular}{|l|c|c|}
\hline \multirow{2}{*}{ Stations } & \multicolumn{2}{|c|}{$\left(\mathbf{H}^{\prime}\right)$} \\
\cline { 2 - 3 } & Dry Season & Wet Season \\
\hline Inlet & 1.34 & 1.48 \\
\hline Center & 1.49 & 1.44 \\
\hline Outlet & 1.51 & 1.08 \\
\hline Cikuda & 1.84 & 1.64 \\
\hline Ciparanje & 1.41 & 1.85 \\
\hline
\end{tabular}

Fig.1 Total genus of phytoplankton during the study

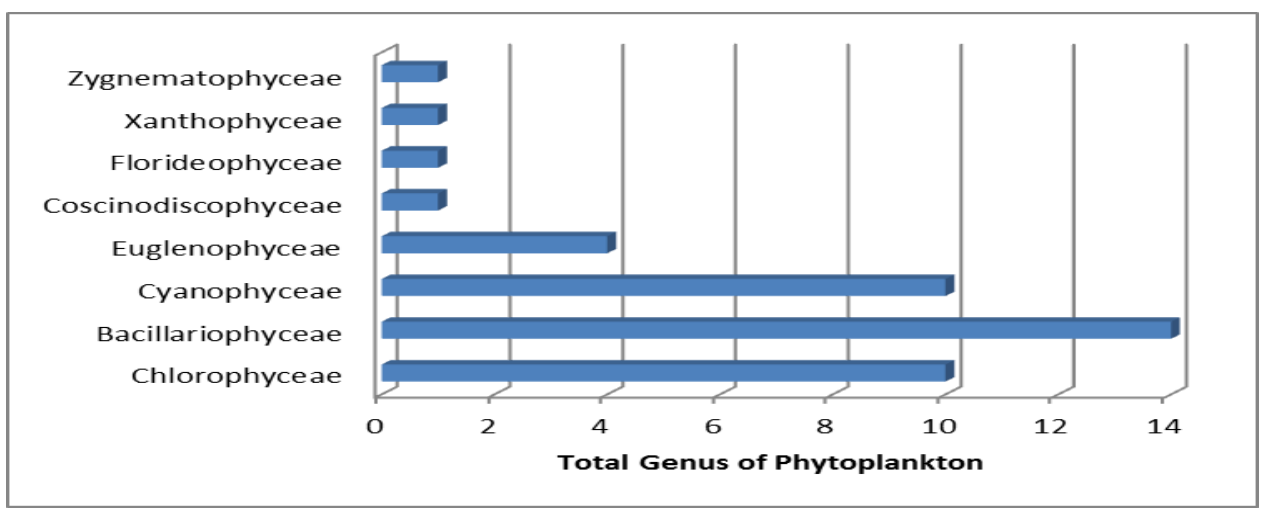

Fig.2 Abundance of Phytoplankton during the different season

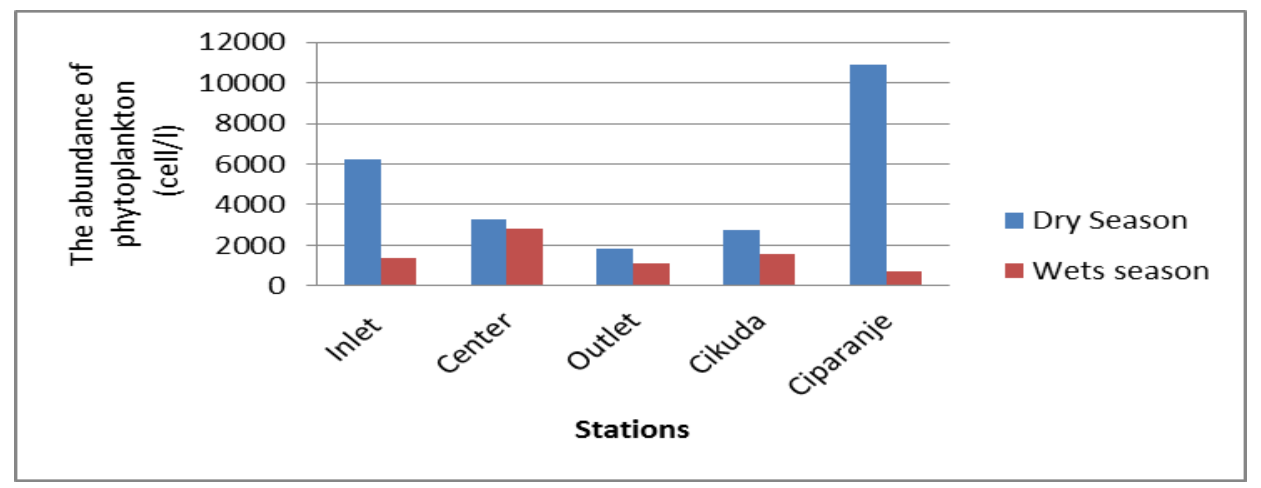


Fig.3 Average of Diversity Index $\left(\mathrm{H}^{\prime}\right)$ of Phytoplankton during the different season

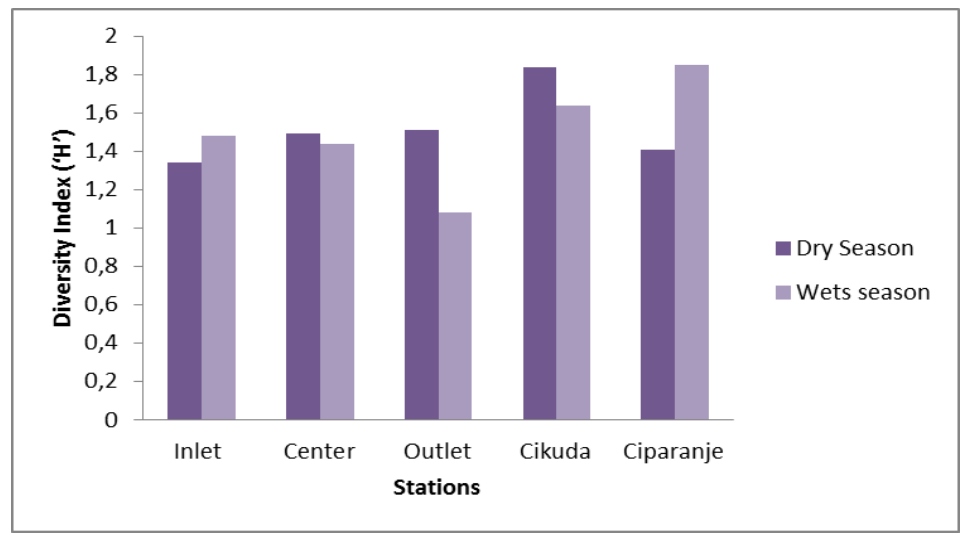

Fig.4 Distribution of chlorophyll-a $\left(\mathrm{mg} \mathrm{L}^{-1}\right)$ during the dry and wet season

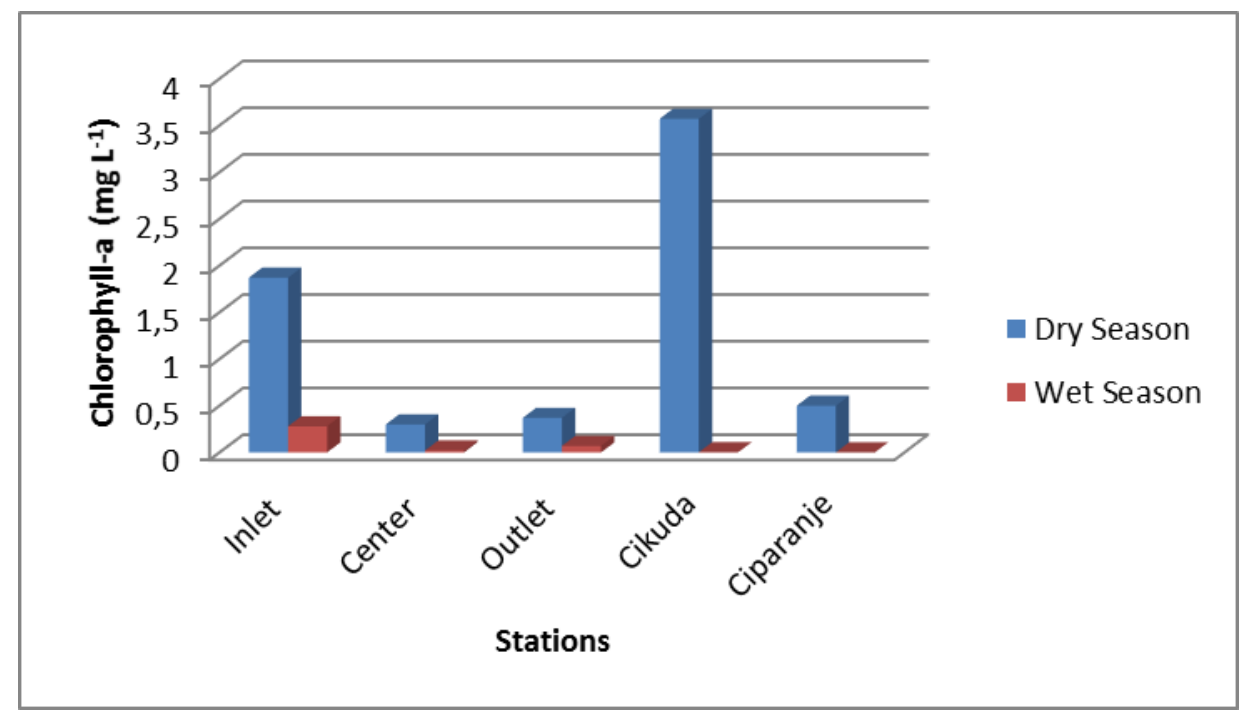

\section{Species abundance}

Phytoplankton density in the five sampling areas (Inlet Check dam UNPAD, Center Check dam UNPAD, Outlet Check dam UNPAD, Cikuda River and Ciparanje) during dry months (July to September 2015) and wet season (December to February 2016) are shown in Table 2 of the 8 major groups identified, Bacillariophyceae were the most abundant phytoplankton in all stations for the five sampling areas in both seasons, followed by the Chlorophyceae and Cyanophyceae. The abundance of Chlorophyceae was also reported by in Yeldari reservoir of Nanded
District, Maharashtra. Pawar and Phulle (2006), recorded Chlorophyceae were found to be dominant throughout the study of Pethwadaj dam in taluka Kandhar of Dist. Nanded, Maharashtra. Malik and Bharti (2012), revealed that Chlorophyceae was dominant in Sahastradhara stream at Uttarakhand. In aquatic ecosystem, calculating phytoplankton biomass are significantly important for determining ecological status. Table 2 shows the relative abundance for dry and wet seasons in the five sampling areas. In the dry season, the station of Ciparanje had 10912.5 cells $\mathrm{L}^{-1}$ and Inlet Check dam UNPAD 6198.3 cells $\mathrm{L}^{-1}$ which 
was dominated by Oscillatoria sp. and Surirella elegans, Fragilaria capucina and Spirogyra sp. respectively the high biomass in dry season could be the result of higher temperature and quantity of essential nutrients (phosphate and nitrate). In the wet season the abundance of phytoplankton was decreased that is may be due to low amount of nutrients and also the entry of the rain water into the research stations, in the wet months the highly biomass were found in the Center Check dam UNPAD 2833.3 cells $\mathrm{L}^{-1}$ and Cikuda River 1554.2 cells $\mathrm{L}^{-1}$ which was dominated by Merismopedia sp. and Gomphonema sp. and Fragilaria capucina.

Shannon-Wiener diversity index (H') were calculated by using the data on phytoplankton species and numerical abundance (cell number). The greater species diversity means larger food chain and more cases of interspecific interactions and greater possibilities for negative feedback control which reduced oscillations and hence increases the stability of the community (Ludwick and Reynold, 1998). Seasonal changes in phytoplankton cell numbers and diversity indices are shown in Table 3. The highest values were 1.85 (wet season in Ciparanje) for Shannon-Wiener diversity index in wet season (Ciparanje), when the highest number of species was determined. The lowest values were $1.08\left(\mathrm{H}^{\prime}\right)$ in the wet season in Outlet Check dam UNPAD, when a low number of species and a high number of individuals were determined, comparison of diversity in the five sampling areas in both the wet and dry seasons, Outlet Check dam UNPAD in the wet season was found to be least diverse based on the Shannon-Wiener diversity index (H') (Fig. 3).

In the present study, this index of diversity ( $\left.H^{\prime}\right)$ shows a value below to 3 for all stations during the study period mention in Table 3. This indicates a low specific structure of these groups indeed, a low diversity characterizes, young settlements of species, while a great diversity indicates mature settlements. The low diversity shows a weak internal structure of population (Le Bris and Glemarec, 1995).

Seasonal variation in diversity index $\left(\mathrm{H}^{\prime}\right)$ of plankton of Check dam, Cikuda and Ciparanje during the dry season was ranged from (1.34$1.84)$ and during the wet season (1.08-1.85). The results of this study indicate seasonal variations in diversity, phytoplankton diversity is high during the dry season. Many studies on phytoplankton diversity showed no direct relationship between nutrient concentration and abundance. It was shown that abundance of phytoplankton during the dry season in waters is negatively correlated with nutrient concentration (Poliat and Isik, 2002). This is attributed to a depletion of nutrients as these were utilized by the phytoplankton for photosynthesis increasing their population size. The results of this study however indicate that increase in abundance during the dry season than in the wet season can be due to continuous supply of high level of nutrients in the water as a result of continuous water run-off from the land and campus UNPAD that it may contain high amount of phosphate and nitrate during the dry months.

\section{Acknowledgments}

The authors are grateful to the Dean, College of Fisheries and Marine Science, Universitas Padjadjaran, Indonesia, for providing necessary laboratory facilities and we also gratefully acknowledge the financial assistance of University Grant Commissions awarded by Rector Univeritas Padjadjaran for supporting this study through ALG project.

\section{References}

Adoni, A. D. (1985): Workbook on Limnology, Pratibha Publishers C-10, 
Gour Nagar, Sagar, India.

APHA., Eaton, A.D., Mary, A. and Franson, H. (2005) Standard Methods for the Examination of Water and Wastewater. American Water Works Association.

Chisti Y. (2007). Biodiesel from microalgae. Biotechnology Advances. 2007; 25: 294-306.

Devassy V. P. and Goes J. I. (1988) Phytoplankton community structure and succession in a tropical estuarine complex (central west coast of India); Estuarine, Coastal and Shelf Science 27 671-685.

Devassy V. P. and Goes J. I. (1989) Seasonal patterns of phytoplankton biomass and productivity in a tropical estuarine complex (west coast of India); Proceedings of the Indian Academy of Sciences (Plant Sciences) 99 485-501.

Edmondson WT (1959). Ward and Whipple's Freshwater Biology. 2nd Ed. Johan Wiley \& Sons Inc., New York, pp.11248 .

Ganai AH, Parveen S, Khan AA, Maryam H (2010). Phytoplankton diversity at Watlab Ghat in Wular lake, Kashmir. Jour. Eco. Nat. Environ. 2(8):140-146.

Kendrim EC (2001). Check list of phytoplankton of Shedam reservoir in Plateau state. Nigerian.J. Aquatic Sci. 16:61-66.

Le Bris, H. and Glemarec, M., (1995), Stands macrozoobenthiques a coastal ecosystem under-saturated with oxygen: the Bay of Vilaine (South Brittany), Oceanologica Acta, 18, pp 573-581.

Lone JA, Kumar A, Kundu S, Lone FA, Suseela MR. (2013). Characterization of tolerance limit in Spirulina platensis in relation to nanoparticles. Water Air Soil Pollut., 2013; 224:1670-6.

Lone, J. A., Lone, F.A., Suseela, M.R. and Toppo, K. (2016). Phycological Studies in Himalayan Dal Lake Ecosystem: Seasonal Composition and Role of
Physico-chemical parameters. International Journal of Current Research Vol. 8, Issue, 05, pp.3014730155, May, 2016.

Ludwik JA, Reynolds JF (1998). Statistical ecology a primer on methods and computing A Wiley-Interscience publication. New York, 1998; 1-337.

Malik DS, Bharti Umesh (2012). Status of plankton diversity and biological productivity of Sahastradhara stream at Uttarakhand, India J. Appl. Nat. Sci. 2012; 4(1):96-103.

Millman M, Cherrier C, Ramastack J (2005). The seasonal succession of the phytoplankton community in Ada Hayden lake, North Basin, Ames, Lowa. Limnology laboratory, Lowa state university, Ames, Lowa.

Pawar SK, Pulle JS, Shendge KM. (2006). The study on phytoplankton of Pethwadaj Dam, Taluka Kandhar, District Nanded, Maharashtra. J. of Aquat. Biol. 21(1):6-7.

Pieterse AJH, Van Zyl JM (1988). Observation on the relation between phytoplankton diversity and environmental factors in the vaal river at balkfontien, South Africa. Hydrobiologia 169:199-207.

Polat, S. and Işık, O. (2002). Phytoplankton distribution, diversity and nutrients at the northeastern Mediterranean coast of Turkey (Karataş-Adana). Turk. J. Botany 26: 77-86.

Pongswat, S., Thammathaworn, S., Peerapornpisal, Y., Thanee, N. and Somsiri, C. (2004). Diversity of phytoplankton in the Rama IX lake, a manmade lake, Pathumthani province, Thailand. Science Asia, 30: 261-267.

Senthilkumar R, Sivakumar K (2008). Studies on phytoplankton diversity in response to abiotic factors in Veeranam lake in the Cuddalore district of Tamil Nadu. J. Environ. Biol. 29:747-752. 
Shannon, C.E. \& Weaver, W. (1949). The Mathematical Theory of Communication. University of Illinois Press, Urbana.

Sridhar R, Thangaradjou T, Senthil Kumar S, Kannan L (2006). Water quality and phytoplankton characteristics in the Palk Bay, southeast coast of India. J. Environ. Biol. 27:561-566.

Szeląg - Wasielewska E (2006). Trophic Status of Lake Water Evaluated Using Phytoplankton Community Structure Change after Two Decades. Polish J.
Environ. Stud. 15(1):139-144.

Tas B, Arif Gonulo I (2007). An ecologic and taxonomic study on phytoplankton of a shallow lake, Turkey. J. Environ. Biol. 28:439-445.

Tiwari A, Chauhan SVS (2006). Seasonal phytoplankton diversity of Kitham lake, Agra. J. Environ. Biol. 27:35-38

Vaulot D (2001). Phytoplankton.Centre Nationale de la Recherche Scientific et Universite Pierre et Marie Curie, Roscoff, France.

\section{How to cite this article:}

Yousif, R.A., Masyamsir, Dhahiyat, Sunarto and Zahidah. 2017. Effect of Physico-Chemical Conditions on the Structure and Composition of the Phytoplankton Community at Jatinangor, Indonesia. Int.J.Curr.Microbiol.App.Sci. 6(11): 4188-4195. doi: https://doi.org/10.20546/ijcmas.2017.611.490 